\title{
COMMUNITY MANAGEMENT OF THE OLÓN COASTAL AQUIFER, ECUADOR, AND ITS IMPACT ON THE SUPPLY OF WATER SUITABLE FOR HUMAN CONSUMPTION
}

\author{
GRICELDA HERRERA-FRANCO ${ }^{1,2}$, LADY BRAVO-MONTERO ${ }^{3}$, PAÚL CARRIÓN-MERO ${ }^{4,5}$, \\ FERNANDO MORANTE-CARBALLO ${ }^{2,6}$ \& BORIS APOLO-MASACHE ${ }^{3}$ \\ ${ }^{1}$ Universidad Estatal Península de Santa Elena UPSE, Facultad de Ciencias de la Ingeniería, Ecuador \\ ${ }^{2}$ ESPOL Polytechnic University, Geo-recursos GIGA, Ecuador \\ ${ }^{3}$ ESPOL Polytechnic University, Facultad de Ingeniería Ciencias de la Tierra (FICT), Ecuador \\ ${ }^{4}$ ESPOL Polytechnic University, Facultad de Ciencias Naturales y Matemáticas (FCNM), Ecuador \\ ${ }^{5}$ Junta Administradora del Sistema Regional de Agua Potable de Olón, Santa Elena, Ecuador \\ ${ }^{6}$ ESPOL Polytechnic University, Centro de Investigación y Proyectos Aplicados a las Ciencias de la Tierra \\ (CIPAT-ESPOL), Ecuador
}

\begin{abstract}
In the north of the province of the Santa Elena province (Ecuador), the important rivers in the area are seasonal, that is, the surface water is intermittent without supplying the population throughout the year. Consequently, the coastal aquifers are managed and exploited by the communes of the sector through the Water Boards. The "Regional Board of the Olón Drinking Water System" (JRAPO, acronym in Spanish), through 7 wells that pump 15 hours a day, supplies water suitable for human consumption to the communities of Olón, Curia, San José, La Núñez and La Entrada. However, when it is beach season, the demand for water increases and at the same time the flow in the wells decreases, generating problems in the water supply to the community members. The objective of this work is to analyze community water management through the social organization of the JRAPO, the technical measures in the water wells and the management of the river with its intermittences for the supply of water to the population. The work methodology includes i) processing of general and specific information on the Olón river-aquifer system, the organization of the JRAPO with its legal framework, ii) geographical territorial scheme of the situation of the Olón basin, iii) analysis of data from the aquifer such as: number of wells, pumping, demand, production and recharge, iv) the interpretation of data and management guidelines that obtain the current supply covering the demand. The results presented allow us to know the average flow of the wells that is around $20 \mathrm{lt} / \mathrm{s}$ and the production based on the pumping of said wells. The water from the wells complies with the requirements of the "Ecuadorian Technical Standard" (NTE) for human consumption in the sector. In conclusion, the analysis of the water management carried out by the community representatives through JRAPO is successful and considers several sections: good community organization, technical component that includes the evolution of the water levels of wells, measurement of the physical parameters. chemicals, well pumping regimes and environmental measures in pursuit of sustainability.
\end{abstract}

Keywords: aquifers, wells, supply, community management, flow.

\section{INTRODUCTION}

Fresh water is an essential water resource for good living and for it to reach each of the homes there is a great system of engineering and resource management, which allows transport and is in good condition for consumers [1]. The government has the obligation to guarantee a good management to take advantage of this resource that can be obtained by rivers, watersheds, aquifers, where its main objective is the optimization of administrative and operational processes to convert any resource into a product of high quality because it represents the source of life for people [2]. Most of the planet's fresh water is under the earth and although groundwater represents a large percentage, pollution is not recognized in them, because its visualization involves hydrological studies, while in surface waters it is quickly 
recognize the source of contamination thanks to its location [3]. The use of groundwater increases every year in different sectors of society, therefore, studies of aquifers and their relationships with the anthropic environment are crucial [4]. The Santa Elena Peninsula (SEP) with 308,693 inhabitants [5], has an arid to semi-arid tropical climate, where average annual temperatures are around $24^{\circ} \mathrm{C}$. In addition, it has a vast availability of natural resources such as water, because it has aquifers, which are responsible for storing groundwater, acting as reservoirs and reserves for this resource [6].

The formation of aquifers is due to surface runoff, precipitation and lakes that give way to infiltration into the subsoil. However, they represent a large part of the total non-frozen fresh water worldwide and a little more than a quarter is distributed for human consumption; the presence of rivers also contributes to the supply of fresh water, but these can also be a source of contamination [7]. The identification of saturation areas in aquifers is of great importance as it facilitates the recharge and sustainability of groundwater. In areas where the water flow rate is high, high porosity and permeability is evident and pollutants can reach the saturation zone faster, and aquifer vulnerability increases [8]. Nowadays, the management of aquifers, due to the important role that groundwater plays in satisfying different types of water consumption needs, is a fundamental component of policies that promote sustainable development [9].

\subsection{Problem statement}

The SEP geographically is located near to the Chongón Colonche mountain range allowing water runoff and helping to recharge aquifers that should supply the communes of the sector. However, its inhabitants, especially in rural areas, have limited access to water suitable for human consumption. This is due, in part, because the Chongón Colonche water transfer system restricted water access in different areas of the province. AGUAPEN-EP was the company responsible for solving the problems by water transfer system, but its pipe network did not reach the northern part of the SEP (see Fig. 1), preventing access to the communities

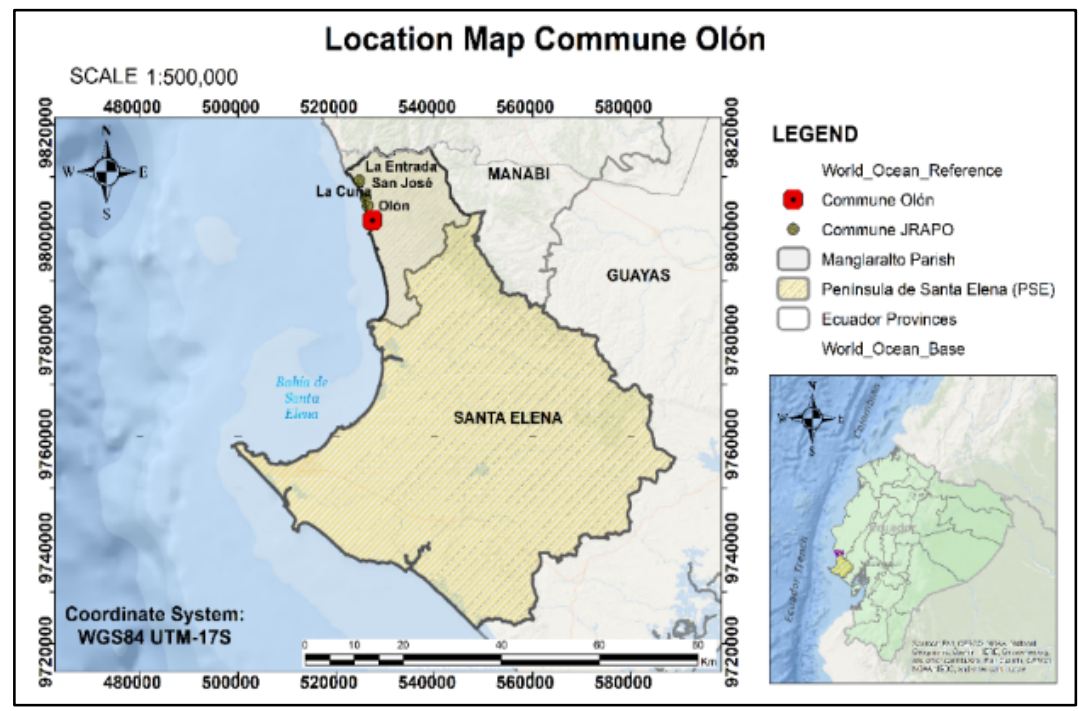

Figure 1: Location Map of the Commune Olón to the north of the PSE. (Source: Adapted from Sistema Nacional de Información [18].) 
present in that sector, which covers the commune Olón, to which the present research is directed [10].

In addition, there is an increase in the demand for water mainly caused by growth both at the level of tourism and the population in the sector, which is why it is not achieved supply this resource in its entirety [11].

On the other hand, the low rainfall $(250 \mathrm{~mm})$ has revealed the fragility of the productive sector, as demand for a coastal aquifer in extreme situations increases [12]. Due to the obvious problem regarding the distribution and access of water, the inhabitants as a community measure to counteract the poor service received by AGUAPEN created the "Regional Board of the Olón Drinking Water System" (JRAPO, acronym in Spanish), which is the entity in charge of properly managing, distributing and recharging this resource to five communities: Olón, Curia, San José, La Núñez and La Entrada and thus comply with the environmental sustainability of the aquifer [13].

This board is responsible for the administration of eight wells and has one delegate for each commune who is responsible for administering the management of aquifer exploration, water supply, purification and commercialization [14]. The primary network managed by the JRAPO was installed 36 years ago through private properties, which makes it difficult to study it, due to the fact that there are wells that are not accessible when found in such properties, which implies possible problems such as the decrease in flow in the network or its contamination due to the fact that no previous studies have been carried out in these wells.

According to the seasons and considering measures of geoelectric and conductivity studies in the wells, decisions are made regarding the implications of high salinity, so in some stages the pumping in some wells has been stopped (P1, P4, P5 and P6) [15]. The situation of what the water board, as a community entity, represents all the attached communities and has the mission of water resource management.

Is it possible that a rural community through its community board with technical advice can supply the water needs of its population?

This paper aims to analyze community water management through the social organization of the board, technical measures in water wells and the management of the seasonal river for water supply to the population. For this, it is important to obtain different parameters such as: flow, recharge, production, demand and pumping of wells, which will allow a diagnosis and analysis of the community management of this resource to be analyzed, analyzing internal and external aspects, related to the participation of the community, and thus through a SWOT matrix, strategies for community management of the aquifer can be proposed.

\subsection{Study area location}

The study area includes the Olón commune (Fig. 1) that has an arid to semi-arid tropical climate, covers an area of $70 \mathrm{~km}^{2}$ along the sub-basin of the Olón river, belonging to the Manglaralto parish, Santa Elena province, Ecuador [13] (Table 1).

The JRAPO provides the water supply to 10,000 people through the coastal aquifer. Historically, threats and risks of floods (during strong winters) and droughts have been identified, also associated with infrastructure deficit problems; as well as landslides and landslides, especially in the areas of cliffs, and strong winds that raise roofs (Table 2).

Another danger is the contamination of sewage from the fishing industry, as well as the waste thrown into river tributaries, marsh areas and estuaries by the shrimp industry in the Playa Bruja sector, the tributaries and leachates of the EMBASUR company-Embase Sudamericano SA canning fish are thrown directly into the sea causing negative impacts to the coastal marine ecosystem [16]. 
Table 1: Hydrographic basins of the Manglaralto Parish. (Source: Adapted from Sistema Nacional de Información [17].)

\begin{tabular}{|l|c|c|}
\hline Watersheds & Extension $\left(\mathrm{km}^{2}\right)$ & Regime \\
\hline Valdivia River & 137.52 & Intermittent \\
\hline Olón River & 53.29 & Intermittent \\
\hline Manglaralto & 65.98 & Intermittent \\
\hline Atravesado & 81.88 & Intermittent \\
\hline Grande River & 161.26 & Intermittent \\
\hline
\end{tabular}

Table 2: Monthly precipitation of Manglaralto Parish. (Source: Adapted from Instituto Nacional de Meteorología e Hidrología, 2013 [19].)

\begin{tabular}{|c|c|c|c|c|c|c|c|c|c|c|c|c|}
\hline \multicolumn{10}{|c|}{ Rainfall values (mm) } \\
\hline Jan. & Feb. & Mar. & Apr. & May & Jun. & Jul. & Aug. & Sep. & Oct. & Nov. & Dec. & Total \\
\hline 107.2 & 39.2 & 102.0 & 2.2 & 11.0 & 25.9 & 30.1 & 8.2 & 12.4 & 29.6 & 13.6 & 3.8 & 385.2 \\
\hline
\end{tabular}

\subsection{Geology}

The Manglaralto parish is formed by forearc basins emergent, whose main tectonic feature is the Chongón-Colonche transverse fault and is located in the intertropical convergence zone that produces threats of hydrometeorological origin (floods, droughts, storms, effects of the El Niño phenomenon and the Nina) and, due to its geomorphological conditions, it supports processes such as landslides, sludge flows and erosion that have negative impacts on the community.

Heavy rains that occur sporadically have affected the coast of this parish, the sea is taking its place and due to erosion the beaches of the communities of San Pedro, Libertador Bolívar, San Antonio, Cadeate, Manglaralto, Montañita, Olón, Curia, San José and Las Núñez are at risk of being destroyed by the intrusion of the sea [17].

The commune Olón is located on some alluvial deposits (Quaternary), with material that is filling the valley of the Olón river, its lithology varies according to the sites of contribution, it has gravels and conglomerates somewhat brecciated, enclosed in a silt-sandy matrix [15], [16].

\subsection{Legal framework of la JRAPO}

The JRAPO was founded on September 11, 1982 and was based on the articles of the law of drinking water boards of Ecuador (Table 3) according to decree No. 3327 official registry No. 80229 of March 1979 [14].

\section{GENERAL METHODOLOGY}

The scheme in Fig. 2 summarizes the Participatory Action Research (IAP, acronym in Spanish) methodology that focuses on finding alternatives that tend to local development of a territory [10]. 
Table 3: Legal framework of the JRAPO. (Source: Adapted from Instituto Ecuatoriano de Obras Sanitarias, 1979 [20].)

\begin{tabular}{|l|l|}
\hline Art. & \multicolumn{1}{|c|}{ Description } \\
\hline 1 & $\begin{array}{l}\text { Authorizes the Ministry of Public Health, so that through the Ecuadorian Institute of Sanitary } \\
\text { Works (IEOS, acronym in Spanish), it organizes and constitutes the Administrative Boards of } \\
\text { Potable Water and Sewerage of the Rural Communities, where these sanitary infrastructure } \\
\text { services are implemented, the same that will be public law entities with sufficient and } \\
\text { necessary autonomy for the functions entrusted to them. }\end{array}$ \\
\hline 2 & $\begin{array}{l}\text { This law and its regulations will govern the operation of the Water and Sewage } \\
\text { Administrative Boards that are created within the parish jurisdiction of the country. }\end{array}$ \\
\hline 3 & $\begin{array}{l}\text { For implementing`s purposes of this law, will understand by rural communities, parish } \\
\text { headers, enclosures, hamlets and others that are not Canton headers. }\end{array}$ \\
\hline 4 & $\begin{array}{l}\text { In the Canton where the Municipal Company of Potable Water works and this covers the } \\
\text { services that by the law corresponds to him in all his jurisdiction, a Potable Water } \\
\text { Administrative Board, organized by the IEOS cannot be constituted. }\end{array}$ \\
\hline 5 & $\begin{array}{l}\text { The administrative boards will count with legal status and own funds that will provide, in } \\
\text { particular, loans made by IEOS, of the rates collected for the provision of services, of } \\
\text { subsidies granted by sectional organisms, as well as donations and contributions received } \\
\text { from private individuals. }\end{array}$ \\
\hline 6 & $\begin{array}{l}\text { The meetings will be composed of dwellers residents in the community, of recognized } \\
\text { solvency and designated through the majority vote of the General Assembly convened for the } \\
\text { purpose by the IEOS. }\end{array}$ \\
\hline 7 & $\begin{array}{l}\text { The charges of the meetings will be honorifics, with the exception of the Treasurer, who will } \\
\text { receive a chord remuneration with the economics availabilities of the same, and for which he } \\
\text { will be cautioned. }\end{array}$ \\
\hline 8 & $\begin{array}{l}\text { If administrator board does not fulfill its intended purposes, for administrative reasons, } \\
\text { financial or technical, IEOS may intervene to restore normalcy of it. }\end{array}$ \\
\hline
\end{tabular}

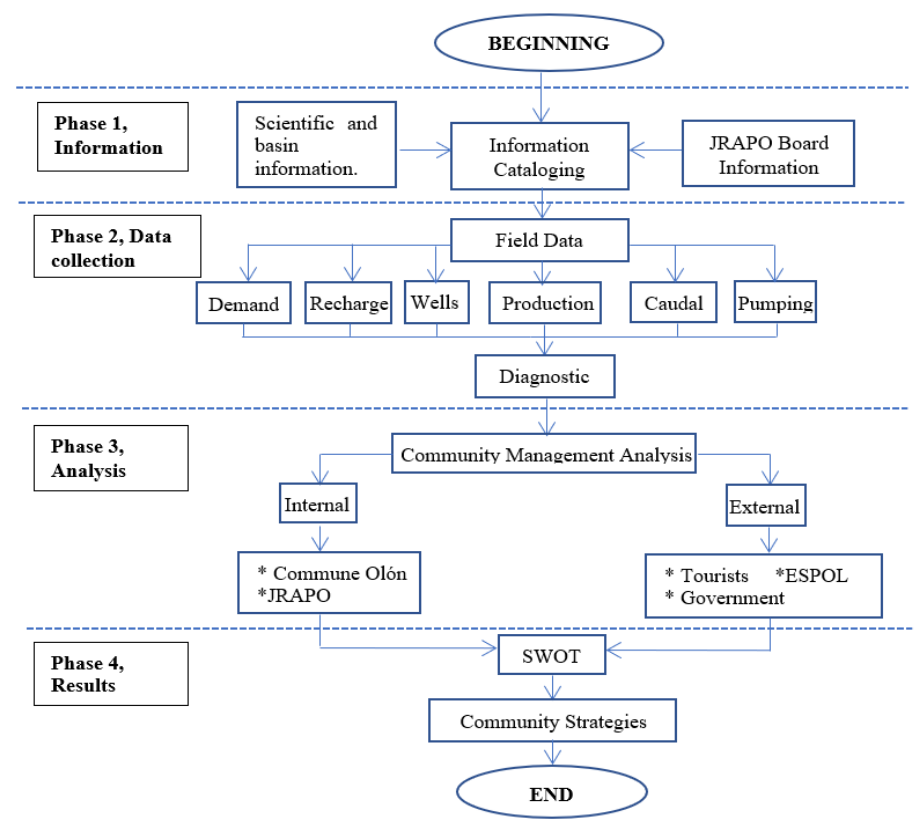

Figure 2: General methodology scheme. 


\subsection{Phase I: Information}

This phase includes the classification of basic information through bibliographic sources, such as thesis, articles, and historical and field reports made in the study area for a preliminary understanding of it.

\subsection{Phase II: Data collection}

This phase covers the information collected through the previous process, as well as field trips to the place in question where data such as: flow, recharge, production, demand, pumping and georeferencing of water wells in the community of Olón were taken. These data were obtained through field trip campaigns in the sector where measurements of physicochemical parameters and static/dynamic levels in the water wells were taken.

\subsection{Phase III: Analysis}

It includes the analysis of Community Management according to internal and external agents through the development of a SWOT, which is a matrix whose acronym means "Strength; Opportunities; Weaknesses and Threats".

\subsection{Phase IV: Results}

It includes the results of the research presenting the community strategies proposed during the study of Community Management in the Olón commune.

\section{RESULTS}

\subsection{Scheme of the situation}

The river-aquifer scheme shown in Fig. 3 consists of the geographical representation of the water wells managed by the JRAPO, as well as the tapes (dikes) built in the area. The sub-basin of Olón is approximately $13 \mathrm{~km}$ long and $4 \mathrm{~km}$ wide.

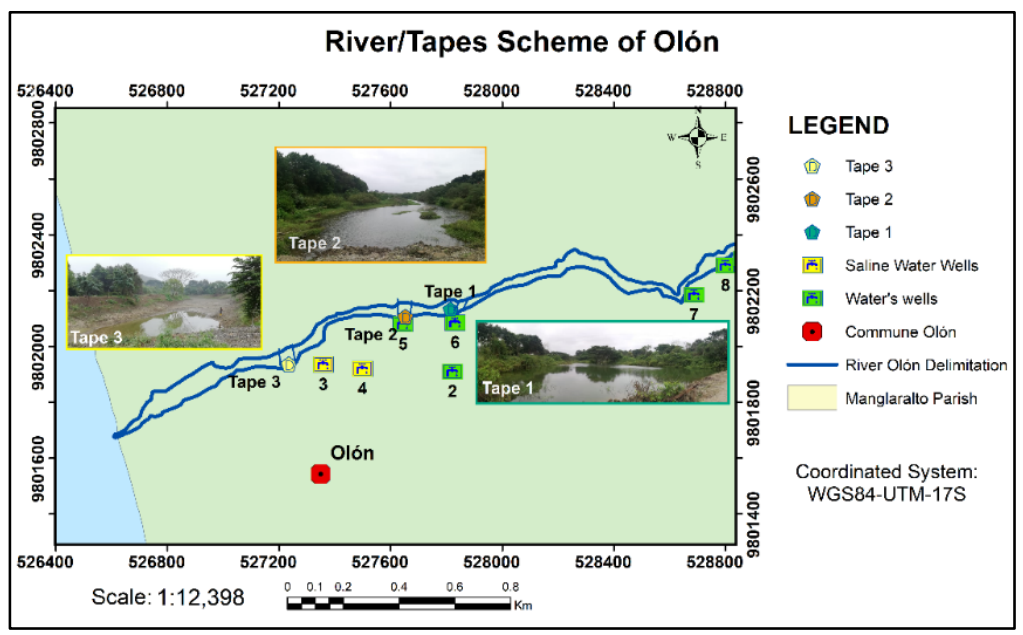

Figure 3: River/tapes scheme of Olón. 
3.2 Data of wells and tapes (dikes) of the commune Olón

The data collected from field trips to the community of Olón, referring to the wells (Table 4) and to the built-up caps (Table 5), are presented below.

Table 4: Well data in months from August to December 2019.

\begin{tabular}{|c|c|c|c|c|c|}
\hline \multirow{2}{*}{ Wells } & \multirow{2}{*}{$\mathrm{X}(\mathrm{m})$} & \multirow{2}{*}{$\mathrm{Y}(\mathrm{m})$} & \multirow{2}{*}{$\begin{array}{l}\text { Depth } \\
\text { (m) }\end{array}$} & Dry season & Rainy season \\
\hline & & & & \multicolumn{2}{|c|}{ Flow (lt/s) } \\
\hline 1 & 527850 & 9802082 & 23 & 7 & 12 \\
\hline 2 & 527834 & 9801922 & 23 & 6 & 12 \\
\hline $3 *$ & 527358 & 9801943 & 27 & - & 15 \\
\hline $4 *$ & 537492 & 9801924 & 23 & - & 15 \\
\hline 5 & 527640 & 9802073 & 23 & 8 & 13 \\
\hline 6 & 527829 & 9802090 & 23 & 15 & 15 \\
\hline 7 & 528685 & 9802189 & 21 & 8 & 13 \\
\hline 8 & 528805 & 9802286 & 19 & 8 & 12 \\
\hline
\end{tabular}

*Wills out of use

Table 5: Location of de tapes (dykes) in Olón in August 2019.

\begin{tabular}{|c|c|c|}
\hline Tapes & $\mathrm{X}(\mathrm{m})$ & $\mathrm{Y}(\mathrm{m})$ \\
\hline 1 & 527815 & 9802133 \\
\hline 2 & 527653 & 9802106 \\
\hline 3 & 527235 & 9801937 \\
\hline
\end{tabular}

Table 6: Representation of results of measurement campaigns physical-chemical parameters.

\begin{tabular}{|c|c|c|c|c|c|c|c|c|c|c|c|c|}
\hline \multirow[t]{2}{*}{ Wells } & \multicolumn{3}{|c|}{$\begin{array}{c}\text { Temperature } \\
\left({ }^{\circ} \mathrm{C}\right)\end{array}$} & \multicolumn{3}{|c|}{$\begin{array}{c}\text { Conductivity } \\
(\mu \mathrm{S} / \mathrm{cm})\end{array}$} & \multicolumn{3}{|c|}{$\begin{array}{c}\text { Salinity } \\
(\%)\end{array}$} & \multicolumn{3}{|c|}{$\mathrm{pH}$} \\
\hline & Aug. & Sep. & Dec. & Aug. & Sep. & Dec. & Aug. & Sep. & Dec. & Aug. & Sep. & Dec \\
\hline 1 & 25.0 & 23.8 & 27.6 & 1024 & 969 & 813 & 0.4 & 0.4 & 0.3 & 7.8 & 7.6 & 7.4 \\
\hline 2 & 26.2 & 24.9 & 27.5 & 1104 & 1119 & 1123 & 0.5 & 0.5 & 0.5 & 7.4 & 7.4 & 7.0 \\
\hline 3 & 26.5 & 26.3 & 25.9 & 4480 & 4520 & 935 & 2.4 & 2.4 & 0.4 & 7.5 & 7.0 & 7.2 \\
\hline 4 & 26.0 & 25.0 & - & 5920 & 5080 & - & 3.2 & 2.7 & - & 7.0 & 7.2 & - \\
\hline 5 & 25.2 & 25.3 & 26.0 & 1069 & 1158 & 926 & 0.5 & 0.5 & 0.4 & 7.7 & 7.8 & 7.3 \\
\hline 6 & 24.7 & 23.8 & 25.3 & 1006 & 969 & 831 & 0.4 & 0.4 & 0.3 & 7.1 & 7.6 & 7.3 \\
\hline 7 & 25.4 & 24.4 & 25.9 & 1025 & 1035 & 971 & 0.4 & 0.5 & 0.4 & 7.5 & 7.5 & 7.4 \\
\hline 8 & 24.6 & 25.6 & 26.2 & 1008 & 1002 & 974 & 0.4 & 0.4 & 0.4 & 7.3 & 7.3 & 7.2 \\
\hline
\end{tabular}

\subsection{Physical-chemical parameters in the wells}

In August and September wells P3 and P4 were out of use due to high salinity issues, in the range of (2.4 to 3.2) and turn a very high conductivity (greater than $5000 \mu \mathrm{S} / \mathrm{cm}$ ), but, in December, all eight wells were already operational. However, it is worth mentioning that it was not possible to take measurements of physical-chemical parameters in water well 4 due to electrical failures in the water pump. The results of the physical-chemical parameter measurement campaigns are summarized in Table 6, where it is observed that wells three and four closest to the coastline have an incidence of probably saline intrusion. 


\subsection{Scheme river-tapes (dykes)}

One of the management measures of the JRAPO, considering the experience of the residents of the community of the Water Board of Manglaralto has been the construction of tapes in the sector, which are a technique that rescues ancestral knowledge and take a tour of (1-2) $\mathrm{km}$ until reaching the sea crossing the most extensive river, in this case, the Olón river with an extension of $12.83 \mathrm{~km}$, where the eight water wells are also distributed (Fig. 3). The main functions of the tapes are contributing to water retention; recharge in the dry season that there are great demands for water and control of saline intrusion.

\subsection{Community management map}

The community water management comes from the Olón coastal aquifer and is related to the river system of the same name, is managed by the JRAPO, which is made up of six members, one of them being president. The management provided by the JRAPO has 37 years of experience in this work and is participatory type because it is carried out jointly with the community members of the sector. This management is summarized in a scheme shown below (Fig. 4).

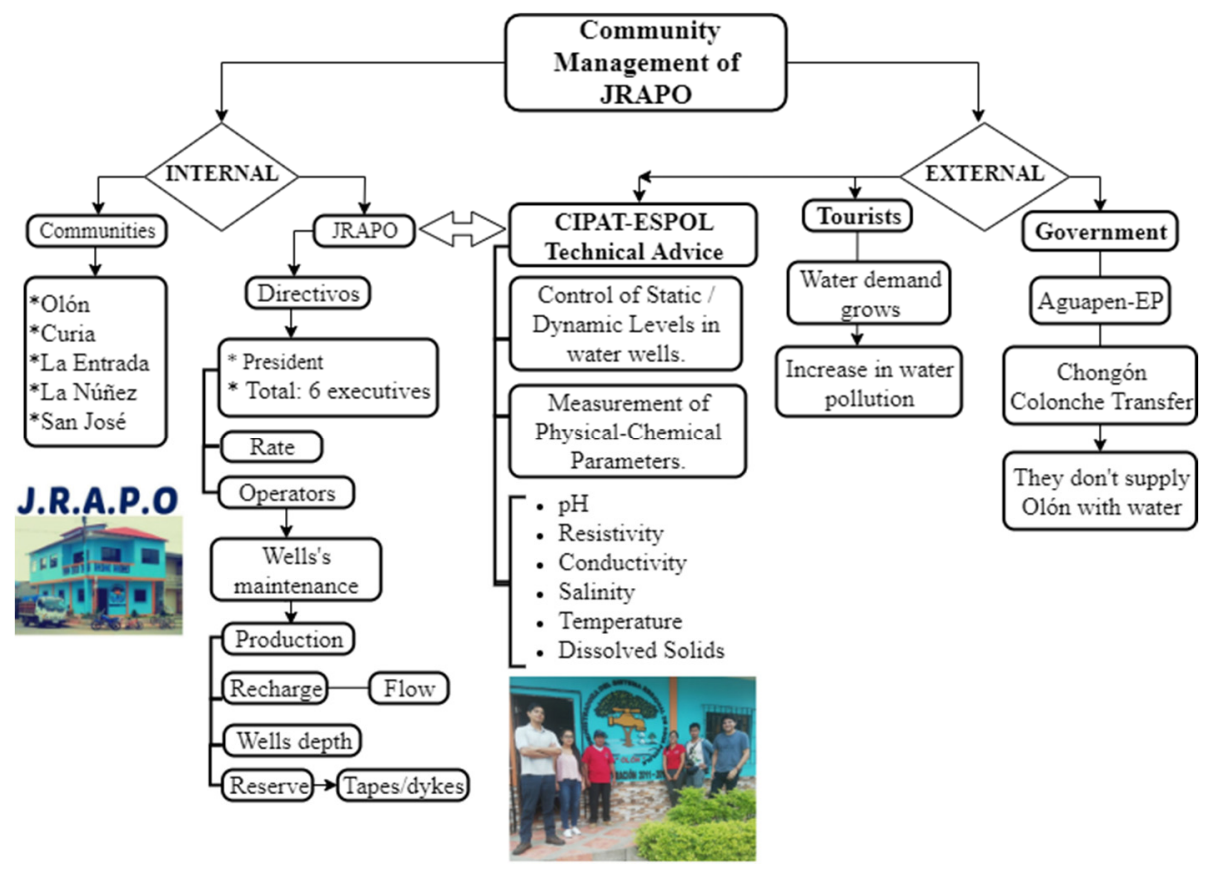

Figure 4: Community management map.

\subsection{SWOT analysis of the JRAPO}

The SWOT matrix whose acronym means "Strengths, Opportunities, Weaknesses and Threats" was created as a methodology to address the external and internal environment of the organization based on external opportunities and threats and internal strengths and 
weaknesses. The SWOT analysis for community management carried out by JRAPO was carried out with an expert review. Based on the results obtained, the implementation of a SWOT matrix was implemented. In order to achieve a correct approach to strategies based on the internal (SW) and external (OT) characteristics of Table 7 and mentioned in Table 8.

Table 7: SWOT analysis of the JRAPO.

\begin{tabular}{|c|c|}
\hline Strengths & Opportunities \\
\hline $\begin{array}{l}\text { - Citizen awareness of good water service in } \\
\text { the sector. } \\
\text { - Experience in the administration of the Water } \\
\text { Board and good relations with neighboring } \\
\text { communities that have more experience in } \\
\text { water management. } \\
\text { - Legal recognition of the JRAPO and its } \\
\text { renewed infrastructure for community service. } \\
\text { - Advising technical-scientific of CIPAT- } \\
\text { ESPOL in the control and extraction of water. } \\
\text { - Rescue of ancestral knowledge by the } \\
\text { community members. } \\
\text { - Community participation in jobs for } \\
\text { tapes (dikes). }\end{array}$ & $\begin{array}{l}\text { - Local government assistance (construction } \\
\text { and/or machinery provided). } \\
\text { - International contribution (IAEA project, } \\
\text { until 2014). } \\
\text { - Collaboration during the 2007-2010 period } \\
\text { by: "The Ecuadorian Italo Fund for } \\
\text { Sustainable Development" (FIEDS, acronym } \\
\text { in Spanish) for the project: Integral water } \\
\text { management in the hands of the community } \\
\text { - Olón. } \\
\text { - International convocations for projects. }\end{array}$ \\
\hline Weaknesses & Threats \\
\hline $\begin{array}{l}\text { - The process of monetary collection by the } \\
\text { water service is weak, presenting problems of } \\
\text { delinquency. } \\
\text { - Lack of technical and management training in } \\
\text { water management, as well as a perimeter of } \\
\text { protection around the wells. } \\
\text { - Lack of economic resources. }\end{array}$ & $\begin{array}{l}\text { - Climate change. } \\
\text { - The rainy season is very short ( } 3 \text { to } 4 \\
\text { months) } \\
\text { - Prone area to saline intrusion due to its } \\
\text { proximity to the sea because it is a coastal } \\
\text { aquifer. } \\
\text { - Pollution of sewage from the fishing } \\
\text { industry. } \\
\text { - Water requirements of closed external } \\
\text { citadels. } \\
\text { - The development of tourism causes an } \\
\text { increase in the demand for water and an } \\
\text { increase in the generation of liquid waste. } \\
\text { Therefore, the extraction and exploitation of } \\
\text { the resource is continuous and mandatory. }\end{array}$ \\
\hline
\end{tabular}

Table 8: TOWS Matrix in the establishment of strategies.

\begin{tabular}{|l|c|}
\hline \multicolumn{1}{|c|}{ Strategies: strengths + opportunities } & Strategies: weaknesses + opportunities \\
\hline $\begin{array}{l}\text { - Formulate national and international projects } \\
\text { with the participation of the JRAPO and the } \\
\text { counseling of CIPAT-ESPOL to improve } \\
\text { water infrastructure and services. }\end{array}$ & $\begin{array}{l}\text { - Manage a complete weather station that } \\
\text { provides information for studies and system } \\
\text { improvement. }\end{array}$ \\
\hline \multicolumn{1}{|c|}{ Strategies: strengths + threats } & \multicolumn{1}{c|}{ Strategies: weaknesses + threats } \\
\hline $\begin{array}{l}\text { - Propose a study of climate change and } \\
\text { environmental impacts that allow us to take } \\
\text { monitoring or control and remediation } \\
\text { measures for sustainability. }\end{array}$ & $\begin{array}{l}\text { - Design a logistics and operation system of } \\
\text { the JRAPO that provides greater agility, } \\
\text { collection and efficiency in its services. }\end{array}$ \\
\hline
\end{tabular}




\section{RESULTS ANALYSIS}

The management of the JRAPO is developed in a participatory way since the community members participate in the board water distribution. The water is extracted from the eight wells located in Olón, as well as the control and maintenance of these wells. At present, some wells have been closed because they are closest to the coastline, and in them, a high conductivity has been detected, this measure has also been corroborated by the high salinity measurements. Then, the wells farthest from the coastline, are those that are in production. In recent years, sometimes, due to climate change (periods of drought), and other times due to the high consumption of water due to the growth in the tourism sector, there have been serious problems in maintaining a supply of perennial water to the community. The water pumped from the wells goes to a storage tank located at a high point, to then distribute the water to the partners using the facilities of gravity. It should be noted that in the storage tank the water is treated with chlorine, complying with the Ecuadorian Technical Standard (NTE) and to offer safe water in the distribution.

The problem of water scarcity and the high demand of the tourism sector has been faced by the method of the rescue of ancestral knowledge, which is practiced in the neighboring hydrographic basins, of other community water boards, such as Manglaralto [21]-[23]. Therefore, in Olón, three "tapes" (engineering dikes) have been built in the riverbed, which retain the original characteristics of the knowledge of the ancestors and built with the same gravel materials, sands, pebbles and boulders of the river itself [24]. These tapes are ubicated relatively near to water wells (Fig. 3), knowing that when there is water accumulation, there is also an artificial recharge of the aquifer.

For the construction of the tapes in this basin, strategically very wide areas are sought to make the tapes, unlike the Manglaralto that seeks the narrowest areas in the riverbed. Both the one and the other design, have different ways to relieve the degree of pressure in the caps, which implies greater recharge for the coastal aquifer. According to Table 6, tape 1 has been strategically located near wells three and four, to rescue, even by dilution, the salinity of the water, showing that the farthest water well It is the one with the most salinity. In any case, the tape is helping to control this process. The community of Olón, also following Manglaralto's reference, is energized through participative processes [21], [25] for them, even in the construction of the tapes there is a very exemplary participatory community work.

Water well management depends on the location, flow and number of wells in operation. From these parameters it is known that there are eight wells in operation, of which, well P3 and $\mathrm{P} 4$ are closed down during times of drought as a measure of sustainability of the aquifer by the evidence of saline intrusion and this is due to its location in the areas closer to the sea (see Fig. 4). As for the flows, during the dry season, they are an average of $8 \mathrm{lt} / \mathrm{s}$, while in the rainy season the average flow is $13 \mathrm{lt} / \mathrm{s}$, because the positive effects of the aquifer recharge. The tapes (dikes) represent the process of Sowing and Harvest of water.

The community management strategies of the Olón aquifer were established based on the SWOT matrix that results from the crossing of certain parameters in Table 8. Thus, strategies have been proposed that guarantee the correct management of the JRAPO listed below:

- Propose a study of climate change and environmental impacts that allow taking monitoring or control and remediation measures for the sustainability of the aquifer.

- Design a logistics and operation system of the JRAPO that provides greater agility, collection and efficiency in its services. 


\section{CONCLUSIONS}

The community management carried out by JRAPO is participatory and works properly due to the openness and interaction of communication between its members, with technical advice from the university (CIPAT-ESPOL). At different stages of community management, studies have been carried out (specifically of Vertical Electric Sounding (VES's) for the location of water wells, construction of water wells, reports for recommendations on the location of tapes (dikes) and the water distribution system, all these details are a service in operation of JRAPO.

The Olón River that go through the study area is seasonal (intermittent), therefore, three tapes have been built that, in addition to rescue ancestral knowledge, contribute to the supply and storage of water by artificially recharging the aquifer during times of drought. This water is naturally clean, which is why it is considered suitable for human consumption since it also goes through a chlorination process go through.

The management carried out by the JRAPO with technical advising from ESPOL directly benefits the inhabitants of Olón since it achieves a better distribution and use of the water resources of the sector through the exploitation of water wells and recharge in the tapes of the sector, solving as much as possible, the problems of water scarcity that arise. Likewise, it contributes to its economic development since largely of the community members are supported by tourism, which depends, in large part, on the availability of drinking water.

\section{ACKNOWLEDGEMENTS}

To the ESPOL Polytechnic University research project "Registro de patrimonio geológico y minero y su incidencia en la defensa y preservación de la geodiversidad en el Ecuador" and to the ESPOL Link Unit project (UVS, acronym in Spanish) "Gestión integral del agua en cuencas hidrográficas de la Parroquia Manglaralto". To the JAAPMAN of Manglaralto and JRAPO of Olón. To Geopark Project "Peninsula Santa Elena" of the Peninsula of Santa Elena University (UPSE, acronym in Spanish). To the projects of the International Atomic Energy Agency (IAEA) "RLA 7/018" and "RLA 7/024".

\section{REFERENCES}

[1] Maganda, C., ¿Agua dividida, agua compartida? Acuíferos transfronterizos en Sudamérica, una aproximación. Estudios Políticos, 32, pp. 171-194, 2008. (In Spanish.)

[2] García, S. \& Francisco, A., La Gestión de Cadenas de Suministros: Un enfoque de integración global de procesos. Visión Gerencial, 1, pp. 53-62, 2006. (In Spanish.)

[3] Mastrocicco, M. \& Colombani, N., A Special Issue of Geosciences: Groundwater Pollution, 2018.

[4] Curtolo, R. \& Bonotto, D., Re-Evaluating Hydrochemical Data from Aquifers occurring in the Rio Claro City Region, São Paulo State, Brazil. Departamento de Petrología e Metalogenia, Instituto de Geociencias e Ciencias Exactas - UNESP, Rio Claro, Brasil. WIT Transactions on Ecology and the Environment, vol. 228, WIT Press: Southampton and Boston, 2018.

[5] Instituto Nacional de Estadística y Censos (INEC), 2010. (In Spanish.)

[6] Ordoñez, J., Contribuyendo al desarrollo de una Cultura del Agua y la Gestión Integral de Recurso Hídrico. Aguas Subterráneas - Acuíferos, Cartilla Técnica: Lima, Perú. 2011. (In Spanish.)

[7] Ramírez, E., Robles, E. \& Ayala, R. \& Martínez, B., Calidad amebológica del agua de pozos utilizados para suministro de agua potable en el Estado de Hidalgo. Ingeniería, 16(3), pp. 219-228, 2012. (In Spanish.) 
[8] Sappa, G., Vitale, S. \& Ferranti, F., Identifying Karst Aquifer Recharge Areas using Environmental Isotopes: A Case Study in Central Italy, 2018.

[9] Cunha, M., An Optimization Model for Aquifer Management under Competition, 2000.

[10] Herrera, G., Estudio para un Modelo de Gestión de un Acuífero Costero, mediante Metodologías Participativas y Análisis Geoestadístico en el marco del Desarrollo Local. Doctoral thesis, Universidad Politécnica de Madrid: Manglaralto, Ecuador, 2015(In Spanish.)

[11] González, M. \& Sánchez, V., Riesgo de contaminación del acuífero arroyo Alamar en Tijuana, Baja California. Región y Sociedad, 25(56), pp. 103-126, 2013. (In Spanish.)

[12] Román, A., Marco, A., Villa, M. \& Catalán, E., Modelación del abatimiento de pozos profundos. Terra Latinoamericana, 29(1), pp. 1-10, 2011. (In Spanish.)

[13] Montalván, F., Caracterización Geoeléctrica del Acuífero de la Cuenca del Río Olón para Propuesta de Plan de Explotación, ESPOL-FICT, p. 100, 2002. (In Spanish.)

[14] Gabino, O., Plan Estratégico Para La Junta Regional Del Sistema De Agua Potable Olón, Parroquia Manglaralto, Cantón Santa Elena, Provincia De Santa Elena, 20132018, 2013. (In Spanish.)

[15] Montalván, F., Caracterización Geoeléctrica de la Cuenca del Río Olón para Propuesta de Plan de Explotación. Tesis de Grado. ResarchGate, 2008. (In Spanish.)

[16] Morante, F. et al., Hydrochemical and geological correlation to establish the groundwater salinity of the coastal aquifer of the Manglaralto River Basin, Ecuador. WIT Transactions on Ecology and the Environment, vol. 229, WIT Press: Southampton and Boston, 2019.

[17] Sistema Nacional de Información (SNI), Plan de Desarrollo y Ordenamiento Territorial de la Parroquia Rural Manglaralto, 2014-2019. (In Spanish.)

[18] Sistema Nacional de Información (SNI), Response Web Site. www.sni.gob.ec. Accessed on: 10 Jul. 2019. (In Spanish.)

[19] Instituto Nacional de Meteorología e Hidrología (INAMHI), Anuario Meteorológico N43-2013. Quito-Ecuador, 2013. (In Spanish.)

[20] Instituto Ecuatoriano de Obras Sanitarias (IEOS), Ley y Reglamento de Juntas Administradoras de Agua Potable, 1979. (In Spanish.)

[21] Herrera Franco, G., Carrión Mero, P. \& Briones Bitar, J., Management practices for a sustainable community and its impact on development, Manglaralto-Santa elena, Ecuador | PrÁcticas de gestión para una comunidad sostenible y su incidencia en el desarrollo, manglaralto-santa elena, Ecuador. Proceedings of the LACCEI International Multi-Conference for Engineering, Education and Technology, Jul. 2019. https://doi.org/10.18687/LACCEI2019.1.1.130.

[22] Carrión, P., Herrera, G., Briones, J., Sánchez, C. \& Limón, J., Practical adaptations of ancestral knowledge for groundwater artificial recharge management of Manglaralto coastal aquifer, Ecuador. WIT Transactions on Ecology and the Environment, vol. 217, WIT Press: Southampton and Boston, pp. 375-386, 2018. https://doi.org/10.2495/SDP180341.

[23] Gricelda, H.F., Paúl, C.M. \& Niurka, A.M., Participatory Process for Local Development: Sustainability of Water Resources in Rural Communities: Case Manglaralto-Santa Elena, Ecuador, World Sustainability Series. https://doi.org/10.1007/978-3-319-63007-6_41, 2018. 
[24] Tierra y Tecnología, La Siembra y Cosecha del Agua en Iberoamérica; un sistema ancestral de gestión del agua que utiliza Soluciones Basadas en la Naturaleza. Response web site. https://www.icog.es/TyT/index.php/2020/02/la-siembra-ycosecha-del-agua-en-iberoamerica-un-sistema-ancestral-de-gestion-del-agua-queutiliza-soluciones-basadas-en-la-naturaleza/. Accessed on: 15 Feb. 2020. (In Spanish.)

[25] Herrera, G., Carrión, P., Sotomayor, P. \& Briones, J. (in Press), Aplicación del conocimiento ancestral mediante albarradas y tapes en la gestión del agua en la provincia de Santa Elena, Ecuador. Boletín Geológico y Minero de España. (In Spanish.) 